\section{Effect of splenic irradiation on circulating colony-forming cells in chronic granulocytic leukaemia}

Patients with chronic granulocytic leukaemia (CGL) have increased numbers of granulocyte colony-forming cells (CFC) in the peripheral blood. ${ }^{1}$ When the disease is controlled by chemotherapy, leucapheresis, or irradiation circulating CFC fall to low levels." ${ }^{2}$ Since irradiation in vitro impairs granulocyte colony growth ${ }^{3}$ the therapeutic effect of splenic irradiation is presumably related to CFC damage, but many factors may operate in vivo to potentiate or diminish the effect. We undertook this study to define the in-vivo action of splenic irradiation on circulating CFC, and to relate changes in CFC numbers to other haematological variables.

\section{Patient, methods, and results}

The patient presented in 1972 at the age of 68 with CGL. A Philadelphia chromosome was present. His condition was successfully controlled with busulphan for two years. In 1975 he developed increasing splenomegaly and his leucocyte count rose to $200.0 \times 10^{9} / 1\left(200000 / \mathrm{mm}^{3}\right)$ despite treatment. A course of splenic irradiation was given to a $13 \times 10 \mathrm{~cm}$ anterior field with ${ }^{60} \mathrm{Co}$ (Mobaltron) in 13 fractions of $75 \mathrm{rad}$ over a period of 28 days to a total of $975 \mathrm{rad}$, during which time his spleen size decreased and his leucocyte count later fell to $8.0 \times 10^{9} / 1$. His condition remained controlled for two months without further treatment before his leucocyte count rose to $30.0 \times 10^{9} / 1$.

The nature of the study was explained to the patient and his consent was obtained. Five $\mathrm{ml}$ blood was taken immediately before and immediately after splenic irradiation for routine blood counts and colony studies. Two hundred cell-differential leucocyte counts were made on a Wright's stained film. Myeloblasts were defined as undifferentiated mononuclear cells with one or more nucleoli. Colony cultures followed the technique described by Pike and Robinson. ${ }^{4}$ Triplicate cultures of $2 \times 10^{5}$ washed buffy-coat cells were plated on normal peripheral blood leucocyte feeder layers. To ensure maximum reproducibility feeder layers were prepared each week from the buffy-coat of one of four subjects who consistently showed good colony stimulation; the same batch of human $\mathrm{AB}$ serum was used throughout.

Absolute numbers of CFC and cluster-forming cells fell progressively during treatment and remained at low levels for 18 weeks. The decline in CFC occurred several weeks before the fall in the total leucocyte count. Immediately after irradiation the absolute number of CFC and clusterforming cells fell on nine out of 11 occasions (fig), the mean ratio of the post:pre value being $0 \cdot 6$. In the first 13 days of treatment $C F C$ and clusterforming cells fell almost linearly, but afterwards numbers of CFC and cluster-forming cells rose on several occasions before the next treatment. Absolute numbers of CFC and cluster-forming cells measured before each irradiation treatment were highly correlated with the absolute myeloblas count $(r=0.96, P=0.0001$ for CFC $v$ myeloblasts, and CFC and clusterforming cells $v$ myeloblasts; $\mathrm{r}=0.89, \mathrm{P}=0.0001$ for cluster-forming cells $v$ myeloblasts). There was no significant correlation between the number of CFC or cluster-forming cells and other blood leucocytes.

\section{Comment}

The results suggest that splenic irradiation is effective in CGL because it damages the CFC circulating through the spleen as well as those resident in the spleen. This implies that the CFC in CGL exchange freely between the blood and the spleen and possibly the bone marrow. The close relation between $\mathrm{CFC}$ and myeloblast numbers in the blood is further evidence that the CFC in CGL morphologically resembles a myeloblast. ${ }^{5}$ A relationship between CFC and myeloblasts probably exists only within individual patients since myeloblast numbers always exceed CFC numbers. Goldman ${ }^{2}$ failed to find a significant relationship between CFC and myeloblasts

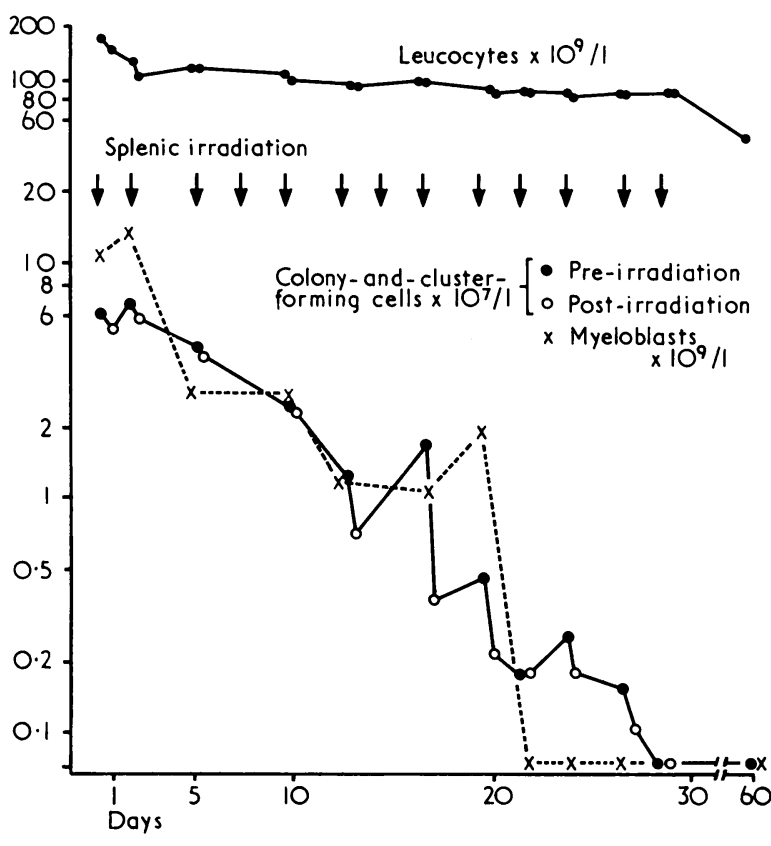

Absolute numbers of colony- and cluster-forming cells, myeloblasts, and total leucocytes during splenic irradiation. Postirradiation myeloblast count is ommitted for clarity.

in single assays on several patients with CGL. Although assays of CFC might be used to monitor the therapeutic effect of splenic irradiation, further studies on patients with CGL would be needed to determine whether the myeloblast count is an accurate indicator of stem-cell response to treatment.

This work was supported by The Andrew Bostic Fund, The Miriam Grenfell Leukaemia Research Fund, and The Bernard Wain Fund, and forms part of an MD thesis by A J B.

Shadduck, R K, and Nankin, H R, Lancet, 1971, 2, 1097.

${ }^{2}$ Goldman, J M, Th'ng, $\mathrm{K} \mathrm{H}$, and Leventhal, R M, British fournal of Cancer, 1974, 30, 1.

${ }^{3}$ Broxmeyer, H E, Galbraith, P R, and Baker, F L, Blood, 1976, 47, 403.

${ }^{4}$ Pike, B L, and Robinson, W A, fournal of Cellular and Comparative Physiology, 1970, 76, 77.

5 Bagnara, G P, et al, Lo Studio in vitro delle Cellule Staminale, ed M A Brunelli, G P, Bagnara, and C Castaldini, p 33. Esculapio, Bologna, 1976.

(Accepted 22 February 1977)

Department of Haematology, Westminster Medical School, London SW1

A J BARRETT, MB, MRCPATH, research lecturer (present address: Centre G Hayem, Hôpital St Louis, 2 Place du Docteur Fournier, Paris 75475 , 10c, France)

P LONGHURST, BSC, research technician

J G HUMBLE, FRCP, FRCPATH, professor of haematology and consultant haematologist, Westminster Hospital

Department of Radiotherapy, Westminster Hospital, London SW1 K A NEWTON, FRCP, FRCR, consultant in radiotherapy and oncology 